Aim of the study: Photodynamic therapy (PDT) is an approved, minimally invasive and highly selective therapeutic approach to a variety of tumors. It is based on specific photosensitizer accumulation in the tumor tissue, followed by irradiation with visible light. The photochemical interactions of the photosensitizer, light and molecular oxygen produce singlet oxygen and other reactive oxygen forms. The imbalance between ROS generation and antioxidant capacity of the body gives rise to oxidative stress in the cell, which initiates cell death in PDT. The aim of this study was to investigate the effect of photodynamic reactions in human melanoma cell lines. Material and methods: Photofrin ${ }^{\circledR}(\mathrm{Ph})$ was used for the photodynamic reaction in vitro as a photosensitizer. The primary cell line was MEWO cell line (granular fibroblasts), derived from a human melanoma. As a recurrent cell line we used Me45 cell line, derived from a lymph node metastasis of skin melanoma. We compared cell viability (MTT assay) to determine the effectiveness of applied therapy. The intracellular distribution of photosensitizer (Photofrin) and localization of mitochondria (MitoTracker Green) were detected by confocal microscopy.

Results: We observed that Me45 and MEWO cell viability was dependent on the time of incubation after irradiation. In the recurrent cell line $\mathrm{Ph}$ accumulated mainly in the mitochondrial membranes and in MEWO cells also in the cytoplasm. The primary melanoma cell line exhibited significantly reduced cellular proliferation (below 50\%) after photodynamic reaction with $\mathrm{Ph}$.

Conclusions: The applied photodynamic reaction was more effective in primary melanoma cells. Additionally, mitochondrial localization of $\mathrm{Ph}$ can lead to disturbances of mitochondrial transmembrane potential and finally to release of apoptotic proteins.

Key words: photodynamic reaction, skin cancer, oxidative stress, Photofrin ${ }^{\circledR}$.

\section{Comparison of the influence of photodynamic reaction on the Me45 and MEWO cell lines in vitro}

\author{
Anna Choromańska', Jolanta Saczko ${ }^{1}$, Julita Kulbacka', Iwona Kamińska², \\ Nina Skołucka ${ }^{1}$, Michał Majkowski ${ }^{3}$
}

1Department of Medical Biochemistry, Wroclaw Medical University, Wroclaw, Poland 2Department of Pathology and Clinical Cytology, Wroclaw Medical University, Wroclaw, Poland

${ }^{3}$ Laboratory of Cytobiochemistry, Biotechnology Faculty, University of Wroclaw, Wroclaw, Poland

\section{Introduction}

Malignant melanoma (lat. melanoma malignum) is a tumor derived from melanocytes - skin pigment cells responsible for melanin production [1, 2]. It is the most severe skin neoplasm as it may grow rapidly and metastasize through blood and lymphatic vessels [3-5]. Previous attempts of multi-agent chemotherapy for treatment of such malignant changes provided an objective response rate of $20 \%$ [6]. In addition, chemotherapeutic agents often lead to secondary tumor resistance [7]. Current melanoma treatment is based mainly on surgical removal by a large marginal of safety $(5 \mathrm{~mm}$ to $2 \mathrm{~cm})$. The most common chemotherapeutic agents used in melanoma treatment are melphalan and dacarbazine $[6,8]$. There is no fully effective treatment and the application of photodynamic therapy (PDT) opens up new perspectives in the therapy of this type of cancer. Photodynamic therapy is based on cooperation of three factors: photosensitizer, which accumulates only in the tumor; light of the appropriate wavelength; and oxygen dissolved in the tissue. Photosensitizer is activated after exposure to appropriate light wavelength. The excitation energy is transferred from the absorption site and then for the production of molecular oxygen $[8,9]$. The photochemical interactions of the photosensitizer, light and molecular oxygen produce singlet oxygen and other forms of reactive oxygen species (ROS). Photodynamic therapy induces disintegration of cellular structures and modulation of genetic information. These changes are caused by oxidative stress and cytotoxic effects in the cell. In recent studies of Kästle et al. the authors observed a high level of ROS after 5-ALA-PDT in WM451LU melanoma cell line [10]. It was presented that WM451LU cells are more susceptible to PDT than normal human keratinocyte cells. The authors suggest that it could be induced by altered metabolism of heme in cancer cells. Leibovici et al. have shown that in cancer cells activity of porphobilinogen deaminase increased significantly as compared to normal cells [11]. Furthermore, Dailey and Smith showed a significant decrease of ferrochelatase activity in various cancer cells [12]. These metabolic changes cause the accumulation of protoporphyrin photosensitizers in cancer cells. Therefore, the concentration of accumulated photosensitizer is significantly higher than in normal cells. Today, the "gold standard" is surgical removal of melanoma. However, there are cases, especially in the elderly, in which it is not possible to perform the operation. Moreover, some melanomas are completely inoperable [13]. Especially the surgical treatment of lentiginous melanoma in the elderly is often problematic [14]. For this reason PDT may be an alternative method of cancer treatment.

The aim of this research was to compare the influence of photodynamic action with Photofrin ${ }^{\circledR}$ on survival of melanoma cells derived from primary 
and secondary cell lines in vitro. Photosensitizer distribution was also evaluated in both types of cells.

\section{Material and methods}

\section{Cell lines}

In the research a secondary melanoma line called Me45 was used. The cell line was obtained from the Oncology Centre Gliwice, where the line was derived from a 35-year-old woman's lymph node cells. The primary line used in experiments was MEWO cell line, purchased from CLS (Cell Lines Service, Germany). The cells were cultured in culture flasks (25 $\mathrm{cm}^{3}$, Falcon) in DMEM (Sigma) with $2 \mathrm{mmol} /$ I glutamine and $10 \%$ fetal bovine serum (FBS, Bio Whittaker, Fetal Bovine Serum, South American origin). The cells were incubated at a temperature of $37^{\circ} \mathrm{C}$ and in the presence of $5 \% \mathrm{CO}_{2}$. Cells intended for experiments were trypsinized (Trypsin-EDTA solution, T4049, Sigma-Aldrich) and then rinsed with PBS.

\section{Photodynamic therapy}

The photosensitizer used in the therapy was Photofrin ${ }^{\circledR}$ (Ph, QLT Phototherapeutics, Inc. Vancouver, Canada). Cells were incubated for $18 \mathrm{~h}$ in darkness with $20 \mu \mathrm{g} / \mathrm{ml}$ Ph in DMEM. Next for 10 minutes it was irradiated with light with power of $10 \mathrm{~mW} / \mathrm{cm}^{2}$ using a lamp (OPTEL, Opole, Poland) with a red filter $(632.8 \mathrm{~nm})[15,16]$. Cells were again incubated in the same conditions for 3,6 or $24 \mathrm{~h}$.

\section{Proliferative test}

Cell survival was assessed by checking cellular mitochondrial activity. Metabolic activity was evaluated using the tetrazolium salt reduction test in cell mitochondria (MTT Assay, Sigma Chemical Co.; 71K8409, In Vitro Toxicology Assay). Mitochondrial activity of living cells was examined in 96-well plates. $3 \times 10^{4}$ cells were placed in each well. The measurements were made on a Multiskan MS microplate reader (Labsystem) at wavelength $570 \mathrm{~nm}$. Results are shown as percentage of control.

\section{Localization of photosensitizer and mitochondria}

Cells were incubated for 4 hours on microscope coverslips in the presence of the photosensitizer. Cells were fixed with $4 \%$ paraformaldehyde, and then rinsed with PBS. To stain the mitochondria, cells were incubated with $100 \mathrm{nmol} / \mathrm{I} \mathrm{Mito-}$ Tracker Green (Molecular Probes, Eugene, OR, a fluorescent dye which stains mitochondria green) for 10 minutes. Such prepared preparations were evaluated using a confocal microscope (LSM510 Meta, Zeiss). For intracellular distribution of photosensitizer a filter with an excitation wavelength $\lambda=$ $=405-753 \mathrm{~nm}$ was applied. To illustrate the cellular mitochondria, a filter with an excitation wavelength $\lambda=488 \mathrm{~nm}$ was used.

\section{Results}

\section{Proliferative test}

There were observed clear differences between the survival of irradiated samples with Photofrin ${ }^{\circledR}$, and the survival of non-irradiated samples (Fig. 1). The viability of MEWO cell line after PDT and $24 \mathrm{~h}$ incubation reached $22 \%$ and for Me45 cell line only $19 \%$. After the same time of incubation, but without irradiation, $83 \%$ of MEWO and $65 \%$ of Me 45 cells survived. The experiment showed that the applied photodynamic method is especially cytotoxic to the primary cell line (Me45). For each time of incubation differences in viability of photodynamically treated cells and non-irradiated samples were significant.

\section{Localization of photosensitizer and mitochondria}

In MEWO cell line the photosensitizer evenly within the cellular cytoplasm and mitochondria, whereas in Me45 cell line it accumulated primarily in mitochondrial membranes (Figs. 2, 3).

\section{Discussion}

Results presented in this paper revealed that applied PDT is cytotoxic to tested human melanoma cells. Cell survival decreased with incubation time after irradiation for both treated cell lines. Particularly sensitive to the applied therapy were primary melanoma cells (MEWO). In both cell lines the localization of Photofrin was observed mainly in mitochondrial membrane, which may lead to induction of intracellular disorders, release of apoptogenic proteins and finally to cell apoptosis [17]. Other researchers have also shown that the application of PDT in melanoma treatment is effective. The authors observed DNA damage in G361 cell line after PDT with porphyrin derivatives, which provoked apoptotic death of malignant melanoma cells [18]. Nowak-Śliwińska et al. proved that Verteporfin and Photofrin used in PDT are highly effective in mouse melanoma S91/I3 Cloudman cells [19]. The researchers observed increasing levels of singlet oxygen in cells, accompanied by a significant decrease in cell survival. Chen et al. found that PDT with methylene blue (MB) caused oxidative stress, which plays an important role in initiating cell death [20]. Our studies show that PDT with

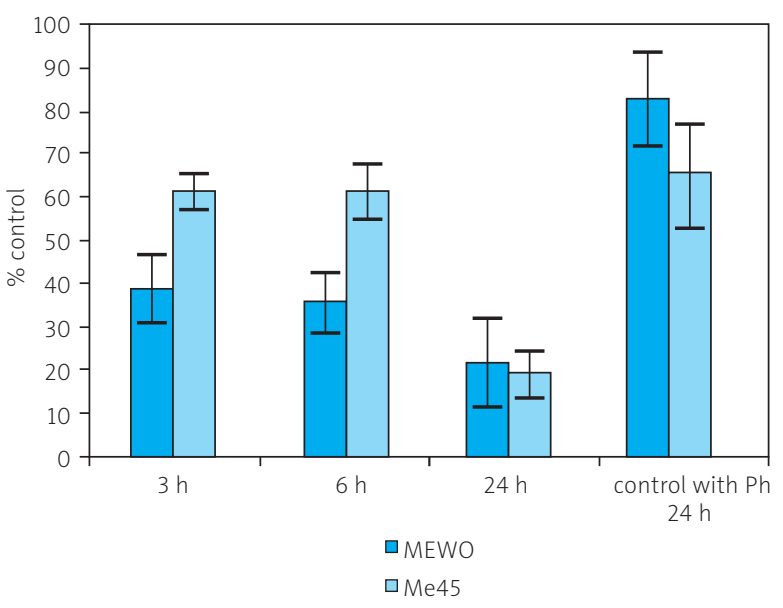

Fig. 1. Evaluation of mitochondria as an indicator of cell survival and ME45 MEWO after photodynamic reaction using $20 \mathrm{mg} / \mathrm{ml}$ of $\mathrm{Ph}$ at a dose of light with a power of $10 \mathrm{~mW} / \mathrm{cm}^{2}$ for 3,6 and 24 hours of incubation after irradiation. Results expressed as mean \pm SD 


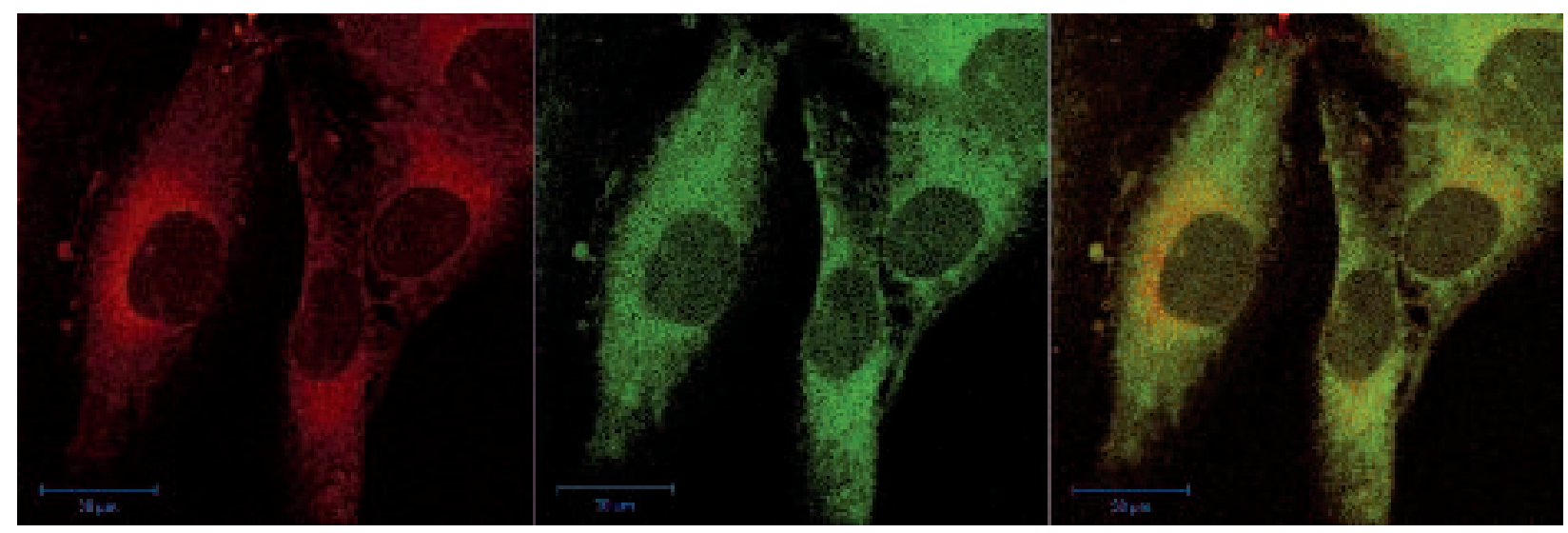

Fig. 2. Distribution of $\mathrm{Ph}$ in MEWO recorded in cells after $4 \mathrm{~h}$ incubation with photosensitizer: A - location of Photofrin ${ }^{\circledR}$; $\mathrm{B}$ - cell mitochondria marker MitoTracker stained MEWO green; C - superimposition of images A and B

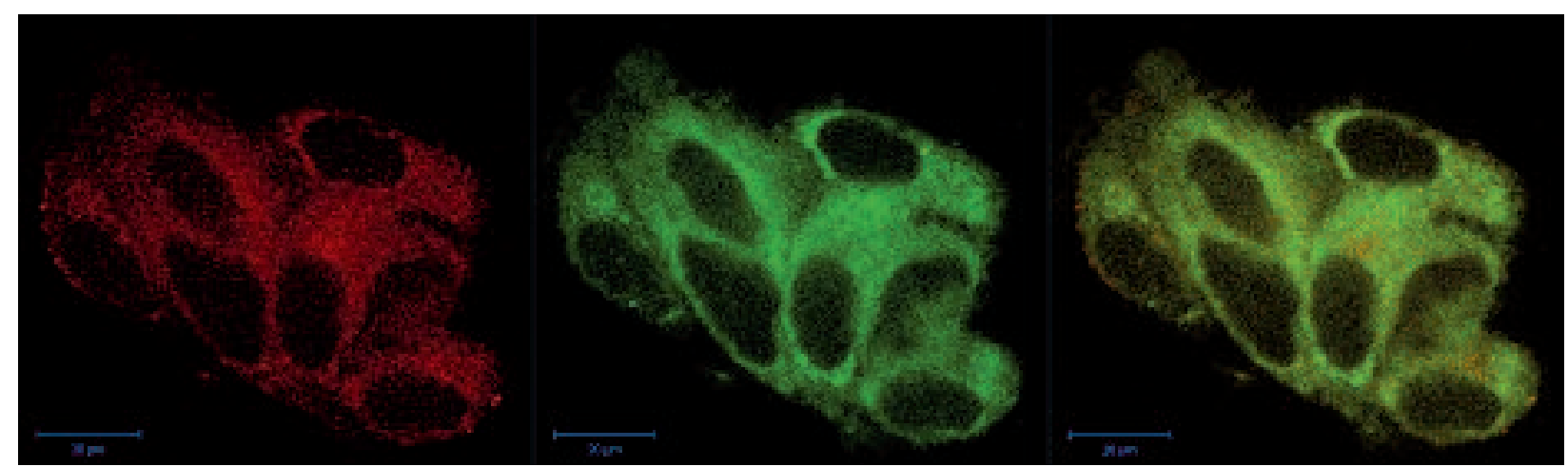

Fig. 3. Distribution of $\mathrm{Ph}$ in Me45 recorded in cells after $4 \mathrm{~h}$ incubation with photosensitizer: A - location of Photofrin ${ }^{\circledR}$; B - cell mitochondria marker MitoTracker stained Me45 green; C - superimposition of images A and B

Photofrin ${ }^{\circledR}$ is a promising technique that can be combined with chemotherapy or radiotherapy, especially in the early stage of melanoma. It can also be a perfect adjuvant therapy after resection of malignant lesions [21]. In conclusion, PDT opens new non-invasive possibilities of melanoma treatment with application of modern developments in molecular biology, chemical synthesis of compounds and optical physics.

\section{Acknowledgments}

The experiments were funded by a PhD grant from the Ministry of Science and Higher Education, no. 5409 /B/P01/2011/40 (project leader: PhD. Jolanta Saczko), and funds of a research project for young scientists of the Medical University of Wroclaw: grant for young scientists no. PBmn1 (project leader: PhD. Jolanta Saczko).

\section{References}

1. Eikenberry S, Thalhauser C, Kuang Y. Tumor-immune interaction, surgical treatment, and cancer recurrence in a mathematical model of melanoma. PLoS Comput Biol 2009; 5: e1000362.

2. Garibyan L, Fisher DE. How sunlight causes melanoma. Curr Oncol Rep 2010; 12: 319-326.

3. Logozzi M, De Milito A, Lugini L, et al. High levels of exosomes expressing CD63 and caveolin-1 in plasma of melanoma patients. PLoS One 2009; 4: e5219.
4. Lens M, Bataille V, Krivokapic Z. Melanoma of the small intestine. Lancet Oncol 2009; 10: 516-521.

5. Ko JM, Velez NF, Tsao H. Pathways to melanoma. Semin Cutan Med Surg 2010; 29: 210-217.

6. Tujakowski J, Roszkowski K, Żurawski B. Wyniki leczenia skojarzonego chemioimmunoterapią czerniaka złośliwego w IV stopniu zaawansowania klinicznego. Wspolczesna Onkol 2005; 6: 269-272.

7. Kuo MT. Redox regulation of multidrug resistance in cancer chemotherapy: molecular mechanisms and therapeutic opportunities. Antioxid Redox Signal 2009; 11: 99-133.

8. Wawrzuta A, Saczko J, Kulbacka J, Chwitkowska A. Czy terapia fotodynamiczna może być zastosowana do leczenia czerniaka? Przegl Dermatol 2009; 96: 240-243.

9. Kulbacka J, Saczko J, Chwiłkowska A, Ługowski M, Banaś T. Fototerapia jako alternatywna metoda leczenia nowotworów. Med Rodz 2008; 4: 88-95.

10. Kästle M, Grimm S, Nagel R, Breusing N, Grune T. Combination of PDT and inhibitor treatment affects melanoma cells and spares keratinocytes. Free Radic Biol Med 2011; 50: 305-312.

11. Leibovici L, Schoenfeld N, Yehoshua HA, Mamet R, Rakowsky E, Shindel A, Atsmon A. Activity of porphobilinogen deaminase in peripheral blood mononuclear cells of patients with metastatic cancer. Cancer 1988; 62: 2297-2300.

12. Dailey HA, Smith A. Differential interaction of porphyrins used in photoradiation therapy with ferrochelatase. Biochem J 1984; 223 441-445.

13. Garbe C, Terheyden P, Keilholz U, Kölbl O, Hauschild A. Treatment of melanoma. Dtsch Arztebl Int 2008; 105: 845-851.

14. Erickson C, Miller SJ. Treatment options in melanoma in situ: topical and radiation therapy, excision and Mohs surgery. Int J Dermatol 2010; 49: 482-491. 
15. Saczko J, Mazurkiewicz M, Chwiłkowska A, Kulbacka J, Kramer G, Ługowski M, Snietura M, Banaś T. Intracellular distribution of Photofrin in malignant and normal endothelial cell lines. Folia Biol 2007; 53: 7-12.

16. Saczko J, Kulbacka J, Chwiłkowska A, Drag-Zalesińiska M, Wysocka T, Lugowski M, Banaś T. The influence of photodynamic therapy on apoptosis in human melanoma cell line. Folia Histochem Cytobiol 2005; 43: 129-132.

17. Das N, Gupta S, Mazumdar S. Direct observation of release of cytochrome c from lipid-encapsulated protein by peroxide and superoxide: a possible mechanism for drug-induced apoptosis. Biochem Biophys Res Commun 2001; 286: 311-314.

18. Kolarova H, Macecek J, Nevrelova P, Huf M, Tomecka M, Bajgar R, Mosinger J, Strnad M. Photodynamic therapy with zinc-tetra (p-sulfophenyl) porphyrin bound to cyclodextrin induces single stand breaks of cellular DNA in G361 melanoma cells. Toxicol in Vitro 2005; 19: 971-974.

19. Nowak-Sliwinska P, Karocki A, Elas M, Pawlak A, Stochel G, Urban ska K. Verteporfin, Photofrin II and merocyanine 540 as PDT photosensitizer against melanoma cells. Biochem Biophys Res Commun 2006; 349: 549-555.

20. Chen Y, Zheng W, Li Y, Zhong J, Ji J, Shen P. Apoptosis induced by methylene-blue-mediated photodynamic therapy in melanomas and the involvement of mitochondrial dysfunction revealed by proteomics. Cancer Sci 2008; 99: 2019-2027.

21. Davids LM, Kleemann B. Combating melanoma: the use of photodynamic therapy as a novel, adjuvant therapeutic tool. Cancer Treat Rev 2011; 37: 465-475.

\section{Address for correspondence}

\section{Anna Choromańska}

Department of Medical Biochemistry

Wroclaw Medical University

Chałubińskiego 10

50-368 Wroclaw, Poland

tel. +48 717841387

e-mail: awawrzuta@gmail.com

Submitted: $\quad 10.02 .2011$

Accepted: $\quad 7.02 .2012$ 